\title{
Identification of Two Tentative Strains of European Subspecies of the Eurasian River Otter Lutra lutra lutra (Linnaeus, 1758) from the Partial Mitochondrial Cytochrome $b$ Gene
}

\author{
Eri $\operatorname{IWATA}^{1) *}$, Harutaka TAIRA ${ }^{2)}$ and Yoshitaka $\mathrm{ABE}^{2)}$ \\ 1) Department of Science and Engineering, Iwaki Meisei University, Fukushima 970-8551, Japan \\ 2) Aquamarine Fukushima, Fukushima 971-8101, Japan
}

[Received 16 June 2014; accepted 30 October 2014]

\begin{abstract}
The Eurasian river otter Lutra lutra is the most widely distributed otter species. The European subspecies L. lutra lutra (Linnaeus, 1758) kept in European zoos has four strains; two of which (the A- and B-lines) have been introduced into zoos and aquariums in Japan. As the genetic backgrounds of, and differences between, these two strains were unknown, we identified partial nucleotide sequences (307bp) of the mitochondrial cytochrome $b$ gene from an A-line and a B-line individual, A-line cyb and B-line cyb, respectively, kept in an aquarium in Japan. The nucleotide sequence of the A-line cyb and B-line cyb showed $98.7 \%$ identity and are distinguishable by the restriction fragment length polymorphism analysis. A-line cyb was 100\% identical to the cytochrome b of L. lutra lutra, whereas B-line cyb failed to show 100\% identity to the known nucleotide sequences on the database. The phylogenetic analysis of our sequences with those from a previous study revealed that the two strains had already been introduced into Japan by at latest the 1990s. These results suggest that there are slight differences between the A- and B-line individuals used in the present study. However, further investigations, including re-evaluation of the taxonomy of $L$. lutra subspecies, are needed to clarify the differences between the two strains.
\end{abstract}

Key words: conservation genetics, cytochrome $b$ gene, Eurasian river otter, Lutra lutra lutra, RFLP

Jpn.J. Zoo. Wildl. Med. 19(4) : 137-142, 2014

\section{INTRODUCTION}

The Eurasian river otter Lutra lutra is the most widely distributed otter species; its habitat ranges across Europe, including parts of Asia and North Africa. The International Union for Conservation of Nature (IUCN) Red List has categorized L. lutra as "near threatened" [1]. Because of the wide habitat range of $L$. lutra, up to 11 subspecies have been reported, including the Japanese river otter L. lutra nippon (Imaizumi et Yoshiyuki, 1989) and the Hokkaido subspecies L. lutra whileleyi (Gray, 1867); the extinction of both of which was recently declared by the Ministry of the Environment of Japan [2]. The lineage relationships of Lutra subspecies are

\footnotetext{
* Corresponding author :

Eri IWATA (E-mail: asealion@iwakimu.ac.jp)
}

not well defined: for example, some taxonomists treat $L$. lutra nippon as the independent species L. nippon.

As of 2013, both the Chinese subspecies L. lutra chinensis (Gray, 1837) and the European subspecies L. lutra lutra (Linnaeus, 1758), also known as European Otter, were being kept in Japanese zoos and aquariums [3]. According to the European Studbook for the European Otter (L. lutra lutra) [4], the captive L. lutra lutra population is separated in four lines; the A-line otters are L. lutra lutra with 100\% known pedigree, the B-line otters are descended from animals bred many years ago at Norfolk Wildlife Park, Great Witchingham, Norfolk, UK, where both $L$. lutra lutra and the Southeast Asian subspecies $L$. lutra barang (Cuvier, 1823) were kept; it is uncertain whether they were ever crossed, the I-line otters are the Iberian ecotype, held in some Spanish zoos especially with Spanish reintroduction in mind, not included within the A-line, and 
the U-line is unassigned line. The genetic backgrounds of, and differences between, these strains are unknown. Among these lines, the A- and B-line L. lutra lutra have been introduced into Japanese zoos and aquariums from European zoos. The policy of the European Endangered Species Programme (EEP) of the European Association of Zoos and Aquariums (EAZA) is to breed only A-line L. lutra lutra and to remove B-line animals from the EEP [4]. However, currently only one A-line animal and 10 B-line animals are being kept in Japanese zoos and aquariums.

A breeding program is to be prepared by the Conservation Committee of the Japanese Association of Zoos and Aquariums [3]. To establish a proper breeding program we need to clarify the genetic backgrounds of both A- and B-line L. lutra lutra. Therefore, here, we determined and compared the partial nucleotide sequences of cytochrome $b$ genes of individuals from the A- and B-lines of L. lutra lutra. We also used restriction fragment length polymorphism (RFLP) to develop a simple method of distinguishing these two strains.

\section{MATERIALS AND METHODS}

DNA samples were obtained from the blood of a male and a female L. lutra lutra kept at Aquamarine Fukushima in Fukushima, Japan. Both individuals originated from European zoos and their strains were clear: the male was A-line and the female was B-line. DNAs were isolated by using a DNeasy Blood and Tissue Kit (Qiagen, Hilden, Germany). A fragment of the mitochondrial cytochrome b gene was amplified by PCR (PCR System 9700, Applied Biosystems, Carlsbad, CA) with a Takara Ex Taq Reaction Kit (Takara Bio, Shiga, Japan), using conserved primers [5] used previously for successful identification of the L. lutra mitochondrial cytochrome $b$ nucleotide sequences [6]. The primers used were;

\section{F1: CATCCAACATCTCAGCATGATGAAA}

\section{R1: CCCCTCAGAATGATATTTGTCCTCA}

The PCR conditions were as follows: initial denaturation at $94^{\circ} \mathrm{C}$ for $5 \mathrm{~min}$; 35 cycles of denaturation at $94^{\circ} \mathrm{C}$ for $0.5 \mathrm{~min}$, annealing at $55{ }^{\circ} \mathrm{C}$ for $0.5 \mathrm{~min}$, and extension at $72{ }^{\circ} \mathrm{C}$ for 1 min; and a final extension at $72{ }^{\circ} \mathrm{C}$ for $7 \mathrm{~min}$, using $10 \mathrm{ng}$ of template DNA. The PCR products were ligated into the pCR 2.1-TOPO vector by using a TOPO TA Cloning Kit (Invitrogen, Carlsbad, CA). Nucleotide sequences were confirmed by DNA sequencing with an ABI PRISM 3730xl DNA Analyzer (Applied Biosystems). Ten clones from each individual were sequenced.
The nucleotide sequences were compared with all other known L. lutra mitochondrial cytochrome $b$ nucleotide sequences by using the Basic Local Alignment Search Tool (BLAST). Partial L. lutra mitochondrial cytochrome $b$ sequences previously reported by Suzuki et al. (1996) [6] and not uploaded to the DDBJ (the DNA Data Bank of Japan)/EMBL (the European Molecular Biology Laboratory)/GenBank databases were also compared. The deduced amino acid partial sequences were obtained from the nucleotide sequences and compared.

A phylogenic tree was constructed by using the neighborjoining method [7] with ClustalX 2.0 and viewed with the NJplot 2.3 program [8]. A sequence of small-clawed otter Aonyx cinerea [6] was used as an outgroup. Bootstrap values were estimated by using 1000 replications [9].

Partial sequences of the Lutra mitochondrial cytochrome $b$ gene were amplified as described, and $12 \mu \mathrm{l}$ of the amplified sample was subjected to endonuclease digestion using the four-base recognition enzyme Afa I. Digestion was performed at $37^{\circ} \mathrm{C}$ for $12 \mathrm{~h}$. DNA fragments were separated on a $1.5 \%$ agarose gel and stained with ethidium bromide; the fragments were made to fluoresce by exposure to ultraviolet light and photographed.

\section{RESULTS}

The 307-bp sequences of mitochondrial cytochrome $b$ were determined from the A-line individual (A-line cyb) and the B-line individual (B-line cyb) (Fig. 1). Single base substitutions were detected at four positions in B-line cyb, which had $98.7 \%$ identity to A-line cyb. Another sequence as found in both the A-line and the B-line; it was considered to be a pseudoform (pseudo cyb) according to the previous studies [6, 10]. The data were registered in the DDBJ/EMBL/GenBank databases and assigned the accession numbers AB933268 (for A-line cyb), AB933269 (for B-line cyb), and AB935512 (for pseudo cyb).

Comparison with previously reported $L$. lutra mitochondrial cytochrome $b$ sequences from a number of specimens obtained from Japan (the subspecies of which were not known) revealed that A-line cyb had $100 \%$ identity to the sequences from two of these individuals. One originated from Latvia and had been kept in a Japanese zoo, and the other was killed by a motor vehicle in Asahikawa in 1989. B-line cyb also had 100\% identity to the sequences from two other individuals of L. lutra, which had originated from China and Europe and had been 


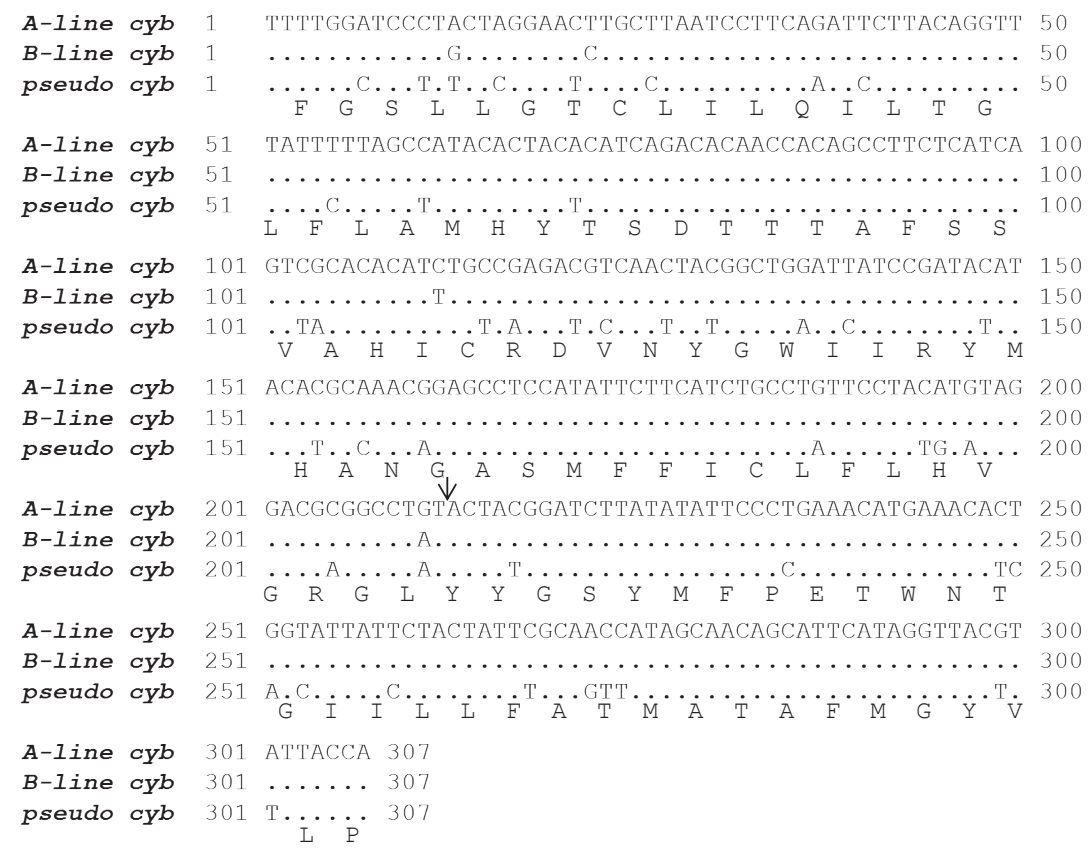

Fig. 1 Comparison of the nucleotide sequences of mitochondrial cytochrome $b$ (A-line cyb and B-line cyb) and its pseudoform (pseudo cyb) in our A- and B-line individuals of $L$. lutra lutura. Nucleotides that are identical to the A-line cyb sequence are denoted with a period (.). The Afa I cutting site is arrowed. The deduced amino acid partial sequence was indicated on the last line.

kept in Japanese zoos [6]. In addition, A-line cyb had 100\% identity to a number of complete nucleotide sequences of European L. lutra lutra cytochrome $b$ gene, such as X94923 [11], EF689068 [12], AJ536010 [13], and AF057124 [14]. In contrast, among these latter sequences no sequence identical to $B$-line cyb was found; B-line cyb had $99 \%$ identity to L. lutra (FJ236015; Jang and Hwang, 2008, direct submission from Korea) and 95\% to L. sumatrana (EF472347) [15]. Our pseudo cyb sequence had $100 \%$ identity to a pseudogene from the above-mentioned L. lutra individual killed in Asahikawa in 1989 [6].

The deduced amino acid partial sequences that we obtained from $A$ - and B-line cyb had 100\% identity (Fig. 1).

We constructed a phylogenic tree from the sequences we obtained, with reference to the previously described sequences (Fig. 2). The A-line cyb and B-line cyb were close to parallel, whereas possible Korean strain of L. lutra (FJ236015) formed a different branch in conjunction with L. sumatrana (EF472347).
The 357 bp fragments of PCR products including the primer sequences were amplified from the DNA samples. The profiles of digestion with Afa I revealed three fragments of PCR product from the A-line individual, namely $237 \mathrm{bp}$ and $120 \mathrm{bp}$ found only in A-line cyb and the $357 \mathrm{bp}$ of the monomorphic pseudogene. The PCR product from the B-line individual was monomorphic (Fig. 3).

\section{DISCUSSION}

We revealed that $L$. lutra mitochondrial cytochrome $b$ partial nucleotide sequences from the A-line and B-line individuals had slight but apparent differences. A-line cyb had 100\% identity to the gene previously found in L. lutra individuals with an unidentified bloodline found in Japan, but it was also completely identical to purebred L. lutra lutra, which means that this is the A-line pedigree. B-line cyb was previously found in L. lutra individuals with another unidentified bloodline in Japan and was slightly different from A-line cyb and also 


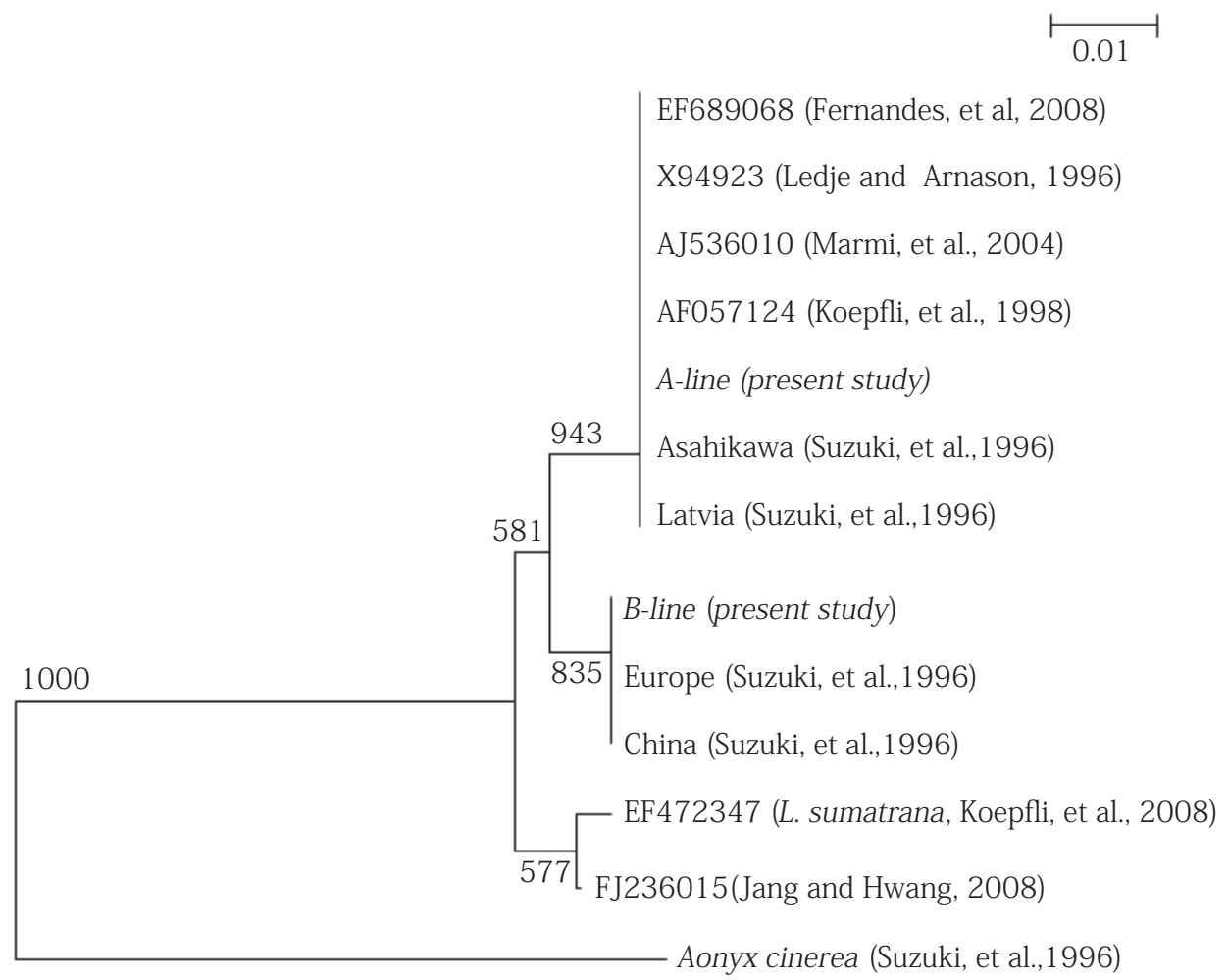

Fig. 2 Phylogenic tree constructed by the neighbor-joining method for mitochondrial cytochrome $b$ in A- and B-line individuals of L. lutra lutra, with reference to the sequences previously described. The sequence from Aonyx cinerea was used as an outgroup. Numbers at each branching point are bootstrap values, as estimated by 1000 replications. Horizontal lines indicate genetic distance.

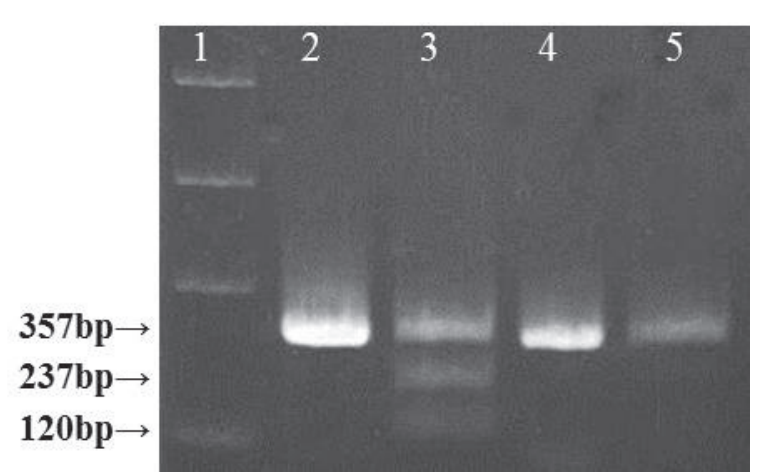

Fig. 3 RFLP fragment profiles of Afa I digestion of the 357bp fragment of Lutra mitochondrial cytochrome $b$ sequences determined from the A- and the B-line individual. 1: Marker (2000, 1000, 500, and 100 bp), 2: A-line cyb PCR product, 3: Afa I digestion product from A-line cyb, 4: B-line cyb PCR product, 5: Afa I digestion product from $B$-line cyb. the sequences of possible Korean strain of $L$. lutra and $L$. sumatrana. However, it is premature to conclude that these differences are characteristic of the B-line. B-line individuals are descended from animals bred in a single zoo, where $L$. lutra lutra and L. lutra barang were kept together, that simply remains possible that there are several crossbred individuals with different genetic backgrounds in B-line. So further analysis, using more samples from B-line L. lutra individuals, is required. Cytochrome $b$ genes are mitochondrial and are thus maternally inherited, so evaluation of the nuclear genome is also necessary to reveal the genetic background of B-line individuals. In addition, comparison with L. lutra barang is needed.

Our comparison with the results of the 1996 study by Suzuki et al. [6] revealed that L. lutra individuals with A- and B-line cyb have been kept in Japan since at least that year. It might therefore be useful for the management of L. lutra pedigrees 
to check Lutra mitochondrial cytochrome $b$ genes of the individuals kept in Japan, including L. lutra chinensis, because the individual originated from China had the same nucleotide sequence as the B-line individual in the present study.

Determination and comparison of complete sequence of cytochrome $b$ genes might be more effective. But the assessment of the fragmentation patterns by using the RFLP method described here would be an easier technique than sequencing, and more suitable for on-site screening.

Our RFLP testing revealed three fragments from A-line cyb, because only A-line cyb had an Afa I restriction-enzyme cutting site. The pseudoform was amplified by PCR at the same time, but it, like B-line cyb, had no cutting site for Afa I (Fig. 1). A number of pseudoforms of Lutra mitochondrial cytochrome $b$ genes have already been reported; these pseudoforms have been amplified with a yield of $30 \%$ to $40 \%$ of the total clones [6]. Moreover, in this study we sequenced 20 clones, and nine of them were sequences of the pseudoform (Data not shown). To discriminate $A$-line cyb from $B$-line cyb by using RFLP we can expect to find, in the case of A-line cyb, three fragments: a dense fragment of $357 \mathrm{bp}$ and two faint fragments of 237 and 120 bp. Even so, the RFLP method used in the present study could discriminate A-line cyb from B-line cyb successfully. If more accurate identification is necessary, the combination of long- and short PCR could be used to avoid the detection of pseudoforms or mitochondrial DNA heteroplasmy.

The phylogenetic analysis of the subspecies of L. lutra from morphological research seemed still confusing. Although L. lutra is the most widely distributed otter species and up to 11 subspecies have been reported, details of the genetic relationships are still being examined [11-15]. After the lineage relationships of the subspecies become clear, there remains the question of the difference between the A- and B-lines and how to deal with these lines in terms of conservation programs in zoos and aquariums in Japan.

\section{REFERENCES}

1. IUCN. 2013. 2013 IUCN Red List of threatened Species, Prepared by the IUCN Species Survival Commission. IUCN, Gland, Switzerland.

2. Ministry of the Environment of Japan. 2012. The 4th Version of the Japanese Red Lists on 9 Taxonomic Groups. Ministry of the Environment of Japan, Tokyo, Japan.

3. Toyama Municipal Family Park Zoo. 2013. Internal Studbook of Eurasian Otter (Lutra lutra) 2013. Toyama Municipal Family Park Zoo, Toyama, Japan (in Japanese).

4. Parc Zoologique de Paris. 2013. European Studbook for the European Otter (Lutra lutra lutra) Number 3 2012. Parc Zoologique de Paris, Paris, France.

5. Kocher TD, Thomas WK, Meyer A, Edwards SV, Pääbo S, Villablanca FX, Wilson AC. 1989. Dynamics of mitochondrial DNA evolution in animals: amplification and sequencing with conserved primers. Proc Natl Acad Sci U S A 86: 6196-6200.

6. Suzuki T, Yuasa H, Machida Y. 1996. Phylogenetic position of the Japanese river otter Lutra nippon inferred from the nucleotide sequence of $224 \mathrm{bp}$ of the mitochondrial cytochrome $b$ gene. Zool Sci 13: 621-626.

7. Saitou N, Nei M. 1987. The neighbor-joining method: a new method for reconstructing phylogenetic trees. Mol Biol Evol 4: 406-425.

8. Larkin MA, Blackshields G, Brown NP., Chenna R, McGettigan PA, McWilliam H, Valentin F, Wallace IM, Wilm A, Lopez R, Thompson JD, Gibson TJ, Higgins DG. 2007. ClustalW and Clustal X version 2.0. Bioinformatics 23: 2947-2948.

9. Felsenstein J. 1985. Confidence limits on phylogenies: An approach using the bootstrap. Evolution 39: 783-791.

10. Bensasson D, Zhang D, Hartl DL, Hewitt GM. 2001. Mitichondrial pseudogenes: evolution' s misplaced witnesses. Trends Ecol Evol 16: 314-321

11. Ledje C, Arnason U. 1996. Phylogenetic analyses of complete cytochrome $b$ genes of the order Carnivora with particular emphasis on the Caniformia. J Mol Evol 42: 135-144.

12. Fernandes CA, Ginja C, Pereira I, Tenreiro R, Bruford MW, SantosReis M. 2008. Species-specific mitochondrial DNA markers for identification of non-invasive samples from sympatric carnivores in the Iberian Peninsula. Conserv Genet 9: 681-690.

13. Marmi J, Lopez-Giraldez JF, Domingo-Roura X. 2004. Phylogeny, evolutionary history and taxonomy of the Mustelidae based on sequences of the cytochrome $b$ gene and a complex repetitive flanking region. Zool Scr 33: 481-499.

14. Koepfli K-P, Wayne RK. 1998. Phylogenetic relationships of otters (Carnivora: Mustelidae) based on mitochondrial cytochrome b sequences. J Zool Lond 246: 401-416.

15. Koepfli K-P, Kanchanasaka B, Sasaki H, Jacques HL. Louie KDY, Hoai T, Dang NX, Geffen E, Gutleb A, Han S-Y. Heggberget TM, LaFontaine L, Lee H, Melisch R, Ruiz-Olmo J, Santos-Reis M, Sidorovich VE, Stubbe M, Wayne RK. 2008. Establishing the foundation for an applied molecular taxonomy of otters in Southeast Asia. Conserv Genet 9: 1589-1604. 


\title{
ミトコンドリアシトクロム $b$ 遺伝子部分配列を用いた ユーラシアカワウソヨーロッパ産亜種 Lutra lutra lutra (Linnaeus, 1758) の暫定的な系統判別法
}

\author{
岩田惠理 ${ }^{1)}$, 平治 隆 $^{2)}$, 安部義孝 ${ }^{2)}$ \\ 1) いわき明星大学科学技術学部 ₹ 970-8551 福島県いわき市中央台飯野 5-5-1 \\ 2) 公益財団法人ふくしま海洋科学館 ９ 971-8101 福島県いわき市小名浜字辰巳町 50
}

[2014 年 6 月 16 日受領, 2014 年 10 月 30 日採択]

\section{要 約}

ユーラシアカワウソは, イタチ科カワウソ亜科のうちでもっとも広い分布域を持つ種である。ヨーロッパの園館で飼育されてい るヨーロッパ産亜種（Lutra lutra lutra）には 4 つの系統があるとされ，そのうち A ラインと B ラインに属する個体が日本国内で 飼育されている。しかしながら, この2系統の遺伝的差異は明らかとされていない。そこで, A ラインと B ラインに属する個体各 1 頭の血液より抽出した DNA を用い, ミトコンドリアシトクロム $b$ 遺伝子の部分配列を決定した。Aラインと B ラインの個体か ら各々 307bp の配列が得られ (A-line cyb, B-line cyb), 両者は 98.7\%の相同性を示した。また, 2 つ配列は制限酵素断片長多 型（RFLP）法によって判別が可能であった。A-line cyb は既報のヨーロッパ産亜種と 100\%の相同性を示したが, B-line cyb はデー タベース上のいずれの配列とも一致しなかった。国内で飼育されていた亜種不明のユーラシアカワウソから得られた既報の配列と 比較を行ったところ, A-line cyb, B-line cyb ともに一致する配列が認められた。以上の結果より, A ラインと B ラインの個体が持 つミトコンドリアシトクロム $b$ 遺伝子にはわずかながら違いが認められたが, これを系統差と断言するためには, ユーラシアカ ワウソ亜種の分類の再検討を含め, 更に詳細な解析が必要であると考えられた。

キーワード : 種の保存, ミトコンドリアシトクロム $b$ 遺伝子, ユーラシアカワウソ, ヨーロッパ産亜種, 制限酵素断片長多型 一日本野生動物医学会誌 19(4)：137-142, 2014

*責任著者 :

岩田惠理（E-mail: asealion@iwakimu.ac.jp） 